of Iran Sacntions In Westers

Printed". Journal of Language

Teaching and Research,

Vol.4,No.6, November 2013,

Finland: Academiy Publisher. 
dan Masa Depan.

diterjemahkan oleh Afrianto

Daud dan Putri Ifa Izzati.

Jakarta: Salemba

Humanika.

Beaugrande,Robert-Alain de dan Ulrich-Dessler,Woflgang

W.1981.Introduction to Text

Linguistics. London: Longman,

Eriyanto. 2001.Analisis Wacana:

Pengantar Analisis Teks Media.

Yogyakarta: LKIS

2002.Analisis

Framing:Konstruksi, Ideologi, dan Politik

Media. Yogyakarta: LKiS.

Fairclough, Norman. 1995. Media Discourse. London: Edward Arnold.

Fiske,John.1990.Introduction to

Communication

Studies.Second Edition.

London and New York:

Routledge.

Jorgensen,Marianne dan Philips,

Louise J. 2007.Analisis Wacana.

Teori

Metode.Diterjemahkan oleh

Imam Suyitno,Lilik Suyitno, Suwarna, Yogyakarta:

Pustaka Pelajar.

Roschco,Bernard.

1999."Newsmaking" Dalam

Howard Tumber(ed).

News.A Reader. New York:

Oxford University Press

Schiffrin,Deborah.1992.Discourse

Markers.Australia:Cambridge

University Press. ,Deborah.1994.Approach

es to Discourse.

Massachusetts: Blackwell

Publisher.

Schudson, Michael. 2003.The Sociology of News.New York: W.W. Norton
A

nd Company, Inc..

Severin,Werner J dan Tankard, James W, Jr. 2005.Communications Theories. Origins, Methods, and Uses in the Mass Media. USA:Longman Publishers.

Shoemaker, Pamela J. dan Reese, Stephen D. 1996.Mediating The Message, Theories of Influences On Mass Media Content. Second Edition, USA: Longman Publishing.

Subagyo P,Ari.2009."Analisis

Wacana Kritis Sebagai Model Kajian Wacana Media Massa di

dalam Anshori, Dadang $\mathrm{S}$ dan Sumiyadi (Ed).Wacana Bahasa.Mengukuhkan

Identitas Bangsa. Bandung: FPBS UPI.

Syarbaini, Syarial, Rusdiyanta, dan Wihardi, 2011.Doddy. Pengatahuan Dasar Ilmu Politik. Bogor:

Penerbit Ghalia Indonesia.

Tuchman, Gaye. 1978.Making News. New York: The Free Press.

Internet dan Jurnal

SAGE PUBLICATION, "Media and Ideology," SAGE PUBLICATION

Online;http://www.sagepub.c om/sites/default/files/upmbin aries/5239 Croteau Chapter 5.pdf (diakses 3 Juni 20014).

Karomani,H.2004. "Pengaruh Ideologi terhadap Wacana Berita dalam Media Massa", Mediator, Vol.5, No.1, tahun 2004.

Yousesefi, Kazem, Bahghban, Alaireza, Shojaeni, Amis.2013."Ideological or International Move? A Critical Discourse Analysis Toward The Representation 
"tak sehat", PAUD penting bagi perkembangan anak,perubahan status PTS menjadi PTN yang berdampak pada ketidakjelasan status SDM di PTN baru. Dalam penulisan teks berita kesepuluh tema tersebut terkait dengan visi-misi masing-masing surat kabar dengan interpretasi masingmasing. Sebagai media massa, Kompas, Media Indonesia, dan Republika memiliki tujuan idealis yaitu memberi edukasi, dan menyalurkan nilainilai baik pada masyarakat. Dalam penerapan tujuan tersebut, media sebagai sebuah organisasi memiliki kepentingan mempertegas ideologi dalam medianya kepada khalayak pembacanya.

Secara sosial dapat dikatakan bahwa mengelola pendidikan tidak mudah dan hal tersebut tercermin dalam 10 tema yang dianalisis. Mengelola pendidikan perlu rutin dan tepat melakukan evaluasi dan revisi meski pendidikan sudah sekian lama diadopsi. Ideologi dalam praktik sosial budaya menggambarkan kebijakan pendidikan di Indonesia.

Keterbatasan penelitian ini terletak pada beberapa tema teks berita yang dianalisis. Teks berita dengan tema-tema peluncuran program pendidikan baru untuk diinformasikan pada masyarakat, kurang optimal dikritisi karena minim hubungan kekuasaan yang tidak sepadan dalam praktik wacana.

\section{Simpulan}

Ideologi dalam teks surat kabar Kompas, Media Indonesia, dan Republika menunjukkan perbedaan dan persamaan. Hampir semua teks berita pendidikan menunjukkan perbedaan ideologi. Persamaan ideo- logi pada ketiga surat kabar tampak pada teks berita bertema hak seseorang yang tercerabut sehingga memunculkan konflik. Berdasarkan elemen linguistik berupa pilihan kata dan tata bahasa, terungkap motivasi ideologis pada Kompas, Media Indonesia, dan Republika. Ketiga surat kabar memiliki kecenderungan dan orientasi ideologis, khususnya pada tema-tema teks berita pendidikan yang bernuansa konflik, untuk mengilustrasikan penggambaran negatif pelaksana pendidikan (lembaga negeri maupun swasta dan Kemendikbud) dan pelaksanaan pendidikan (seleksi masuk, pelaksanaan ujian, penerapan kurikulum) sehingga dapat dikatakan pelaksana dan pelaksanaan pendidikan di Indonesia tidak bijaksana, tidak taat aturan, ingkar janji, dan salah manajemen. Ideologi dalam praktik wacana menggambarkan faktor-faktor yang mempengaruhi produksi teks yaitu memuat atau tidak memuat, rutin media dan kesegeraan, memilih, dan memilah, serta mempengaruhi pandangan khalayak pembaca; dan pengaruh dalam pengonsumsian teks yaitu mengonsumsi informasi yang tersebar luas, dan mengandalkan informasi media massa.Ideologi dalam praktik sosial budaya menggambarkan kebijakan pendidikan di Indonesia.

\section{Referensi}

Baker,Paul dan Ellece,Sibonite. 2011.Key Terms in Dicourse

Analysis. New York:Continuum International Publishing Group Baran, Stanley J, dan Davis, Dennis K. 2009.Teori Komunikasi Massa. Dasar Pergolakan, 
logi konsumsi teks di atas, berkut ini ideologi dalam konsumsi teks: ideologi mengonsumsi informasi yang tersebar luas, ideologi integrasi media digital, ideologi mengikuti agenda media, ideologi mengonsumsi isi berita sesuai kebutuhan, dan ideologi mengandalkan informasi media massa.

\section{Praktik Sosial Budaya}

Secara situasional, institusional dan sosial, sepuluh tema-tema pendidikan yang dimuat surat kabar Kompas, Media Indonesia, dan Republika dapat menggambarkan kondisi pendidikan Indonesia. Penggambaran dalam teks berita ketiga surat kabar berlangsung dalam kehidupan keseharian dunia pendidikan Indonesia.

Dilihat dari kondisi situasional, teks-teks berita pendidikan dalam Kompas, Media Indonesia, dan Republika terbit dalam masa tiga bulan di paruh awal tahun 2014 yaitu bulan Maret hingga Mei 2014. Rentang waktu tersebut adalah masamasa menjelang akhir pemerintahan Kabinet Indonesia Bersatu II (KIB II), kabinet pemerintahan Indonesia pimpinan Presiden Susilo Bambang Yudoyono dan Wakil Presiden Boediono hasil pemilihan presiden tahun 2009 dengan masa tugas tahun 2009-2014. Masa pemerintahan KBI II, merupakan tahapan kehidupan sosial dan politik di alam reformasi. Pers di masa ini lebih bebas dibanding masa sebelum reformasi. Konsekuensinya pers lebih berani melakukan kritik pada lembaga maupun orang, baik di lembaga pemerintahan maupun non-pemerintahan. Tematema tentang pendidikan yang dimuat Kompas, Media Indonesia dan
Republika karena dinilai oleh ketiga surat kabar memiliki news value yaitu memiliki unsur faktual, penting (significance), kedekatan (proxymity), human interest, dan timelines (baru saja terjadi/aktual), dan konflik. Dalam kaitan dengan faktorfaktor yang mempengaruhi isi media, sebagai contoh rutin media,tematema terseb ut dimuat oleh Kompas, Media Indonesia, dan Republika karena masing-masing surat kabar memiliki rubrik khusus pendidikan dan tema-tema tersebut memiliki news valuesehingga ketiga surat kabar perlu menginformasikan pada masyarakat umum agar memahami situasi pendidikan,misalnya tema banyaknya PTS "tak sehat".

Dari segi institusional, Kompas, Media Indonesia, dan Republika memuat tema-tema pada kurun Maret hingga Mei 2014 karena ingin memenuhikebutuhan dan keinginan khalayak pembacanya terhadap informasi,selain menjalankan fungsi media massa sebagai pengawas lingkungan (surveilance) dan pendistribusi informasi. Teks berita yang ditulis beragam temanya; ada berita baik bagi masyarakat yaitu mengenai kesempatan belajar melalui kuliah terbuka online gratis dan SMA terbuka; berita agar masyarakat lebih tahu dan lebih memahami bagian dari pendidikan di Indonesia yang bermasalah dan kontroversial seperti tema Ujian Nasional (UN) dan Kurikulum 2013, ada berita dengan tema yang sensitif yaitu diskriminasi seleksi nasional masuk PTN terhadap kaum difabel, dan selebihnya topiktopik yang mesti dilaporkan media sebagai bentuk pengawasan karena informasi tersebut penting dan perlu diketahui khalayak antara lain PTS 
dan Republik sebagai surat kabar nasional memiliki eksposur yang luasyaitu hampir di seluruh kotakota besar di Indonesia sesuai sirkulasi masing-masing. Dengan begitu efek kognitif pemberitaan ketiga surat kabar bersifat nasional. Efek kognitif membuat khalayak pembacanya tahu, lebih tahu, teringat kembali, dan memahami suatu tema pendidikan lebih mendalam Jika melihat pada oplah,Kompas memiliki eksemplar terbanyak dari ketiga surat kabar nasional yang dianalisis yaitu 600. 000 eksemplar yang artinya selain menjangkau khalayak pembaca dalam cakupan nasional, juga mengenai khalayak dalam jumlah besar. Tentu, meski Media Indonesia dan Republika, sirkulasinya 'hanya' sekitar separuh eksemplar Kompas, dua surat kabar ini pun menjangkau khalayak pembaca yang cukup besar dan dalam jangkauan nasional di puluhan propinsi di Indonesia.

Dari sisi demografi, Kompas, Media Indonesia, dan Republika, dibaca oleh kalangan SES menengah dan terdidik. Melihat pada karakteristik tersebut, mereka memiliki kesempatan leluasa pada jenis media lain atau media sejenis lainnya sehingga dapat membandingkan Kompas, Media Indonesia, dan Republika dengan surat kabar lain, baik cetak maupun online, dan juga wacana interpersonal dengan orangorang yang memiliki posisi baik dalam masyarakat dan tereksposur informasi mutahir lebih cepat dari orang pada umumnya.

Mengacu pada teori Agendasetting, apa yang dituliskan media itu penting bagi media, dan penting pula bagi pembaca.Meski demikian, pem- baca adalah khalayak yaitu aktif memilih yang perlu dibacanya sesuai motif mengonsumsi surat kabar Kompas, Media Indonesia, dan Republika. Mengacu pada pendekatan penggunaan dan kepuasan (uses \& gratification approach) bahwa khalayak aktif memilih isi surat kabar, sesuai kebutuhannya yaitu kebutuhan kognitif, kebutuhan afektif, kebutuhan integratif personal dan kebutuhan integratif sosial. Mengacu pada teori Ketergantungan Sistem Media disebutkan bahwa ketergantungan pada media massa terjadi karena keadaan sistem sosial, peran media dalam sistem tersebut, dan hubungan khayalak dengan media. Efek terjadi karena media bekerja dengan cara tertentu untuk memenuhi kebutuhan dan keinginan khalayak tertentu. Salah satu yang menyebabkan khalayak pembaca Kompas, Media Indonesia, dan Republika tergantung pada ketiga surat kabar ini karena kebutuhan khayalak untuk memahami informasi tentang dunia sekeliling dari sumber terpercaya, dalam hal ini narasumber yang kompenten menjelaskan tentang suatu peristiwa pendidikan, selain juga surat kabar Kompas, Media Indonesia, dan Republika dipercaya karena reputasinya.

Wacana media surat kabar cetak,berdampak kuat pada masyarakat, utamanya dalam pengetahuan dan pembentukan opini publik. Ideologi dalam teks yang diproduksi mempengaruhi pikiran pembaca dalam memandang suatu peristiwa maupun orang yang diberitakan. Teks berita dengan ideologi tertentu dapat memunculkan pemahaman dan pemikiran tertentu pada pembacanya. Dari penggambaran ideo- 
pelaku, sedangkan Media Indonesia sebaliknya yaitu dominan untuk menonjolkan orang, peristiwa atau situasi tertentu. Ketiga surat kabar dominan menggunakan modalitas "harus" yang mengungkapkan keharusan atauperintah yang menunjukkan otoritas atau kekuasaan media,dan modalitas "akan" yang mengungkapkan maksud atau keakanan, memperlihatkan kepastian yang tinggi, yang menunjukkan media dapat memastikan apa yang akan terjadi. Dalam intertekstualitas,ketiga surat kabar mengutamakan nara sumber pemerintah, dan penggunaan kutipan tidak langsung lebih banyak daripada kutipan langsung oleh Kompas dan Republika,sedangkan pada Media Indonesia sebaliknya. Ini artinya pemerintah merupakan narasumber penting dan utama karena kedudukannya sebagai pembuat dan pelaksana kebijakan pendidikan di Indonesia. Penggunaan kutipan langsung dapat diartikan pernyataan yang diucapkan penting,tajam,dan dramatis dari sumber otoritatif.Media menyediakan cukup ruang untuk kutipan langsung menunjukkan komitmen untuk menunjukkan bentuk pasti kata-kata yang digunakan. Penggunaan kutipan tidak langsung dapat diartikan menunjukkan gaya ambivalensi.

\section{Praktik Wacana}

Dalam produksi teks, media massa menetapkan memuat atau tidak memuat suatu tema berita tentang pendidikan baik berupa peristiwa, tindakan maupun proses, mengacu pada teori Agenda-setting terkait dengan strategi priming yaitu menetapkan tema yang dianggap penting oleh redaksi Kompas, Media
Indonesia, dan Republika untuk dimunculkan di masing-masing surat kabar, selain strategi framing yaitu memilih dan memilah fakta yang akan dijelaskan pada bagian selanjutnya.

Pada level rutin media, berita pendidikan perlu dituliskan karena mengandung nilai berita. Selain alasan rutin, isi media juga dipengaruhi oleh institusi di luar media atau media ekstra. Dalam pengaruh rutin media adalah surat kabar rutin memuat topik pendidikan karena memang tersedia rubrik khusus yang memuat tema pendidikan dalam Kompas, Media Indonesia, dan Republika. Rutin mediadalam hal memilah dan memilih tema pendidikan, diterapkan karena realitas dunia demikian banyaknya. Dalam pemilihan dan pemilahan, level organisasi dan ekstra media berperan.Dalam penggunaan narasumber pemerintah, misalnya, level organisasi, ideologi, dan ekstra media memiliki pengaruh yang signifikan. Narasumber Kemendikbud sebagai lembaga yang mengurusi pendidikan di Indonesia, penting dikutip pendapatnya.

Dalam memproduksi berita, Kompas, Media Indonesia, dan Republika melalui serangkai pertimbangan yang dilakukan karena fungsinya dalam masyarakat dan sebagai proses yang tak terhindarkan mesti dilalui dalam produksi teks. Penggambaran ideologi produksi teks di atas, ditemukanideologi dalam produksi teks adalah ideologi memuat atau tidak memuat, ideologi rutin dan kesegeraan,ideologi memilih dan memilah fakta, dan ideologi mempengaruhi pandangan khalayak.

Dalam konsumsi teks, surat kabar Kompas, Media Indonesia, 
sistem pemikiran (system of thought).(Syarbaini,Rusdiyanta,Wiha rdi,2011:157).Ideologi dalam pandangan Geerzt adalah sistem budaya (cultural system) yang mengandung pengetahuan, kepercayaan, norma dan nilai yang diyakini masyarakat sebagai suatu realitas kebenaran. Ideologi bisa dipahami sebagai suatu ide atau gagasan yang mempunyai kekuatan yang mendorong tindakan seseorang untuk mencapai gagasan tersebut(Karomani,2004: 39).

Raymond William menyatakan ideologi dalam 3 ranah yaitu 1) sebuah sistem kepercayaan oleh kelompok atau kelas tertentu, sebagai seperangkat sikap yang dibentuk dan diorganisasikan secara koheren; 2) sistem kepercayaan yang dibuat yang bisa dilawan dengan pengetahuan; seperangkat kategori yang dibuat dan kesadaran palsu ketika kelompok yang berkuasaan menggunakannya untuk mendominasi kelompok lain yang tidak dominan;3) proses umum produksi makna dan ide.Ideologi dalam pengertian ini untuk menggambarkan produksi makna. (Fiske, 1990;164)

Pendapat lain yang kira-kira sama mengenai ideologi adalah bahwa ideologi berhubungan dengan konsep-konsep seperti pandangan dunia (worldviews), sistem kepercayaan (belief system) dan nilai-nilai (values), namun ideologi lebih luas daripada terminologi-terminologi tersebut. Ideologi merujuk tidak hanya pada kepercayaan tentang dunia tetapi juga pada cara dasar bagaimana dunia didefinisikan(Sage $\mathrm{Pu}-$ blication Online,2014).

Pernyataan yang dikemukakan para ahli bahwa wacana media menggambarkan ideologi media dan ideologi dalam media perlu dianalisis lebih dalam maka tujuan penelitian ini untuk memperoleh pemahaman yang mendalam tentang ideologi dalam 1) teks berita pendidikan surat kabar Kompas, Media Indonesia, dan Republika; 2)praktik wacana,yang terdiri dari produksi teks dan konsumsi teks surat kabar Kompas, Media Indonesia, dan Republika; dan 3) praktik sosial budayadalam produksi teks berita pendidikan surat kabar Kompas, Media Indonesia, dan Republika.

\section{Metodologi}

Pendekatan penelitian adalah kualitatif dengan metode analisis isi, menerapkan metode teori analisis wacana kritis Norman Fairclough yang

Terdiri dalam tiga level yaitu teks, praktik wacana, dan praktik sosial budaya.Sumber data adalah berita-berita pendidikanyang dimuat Kompas, Media Indonesia dan Republika dalam kurun 3 bulan di tahun 2014terdiri dari sepuluh tema yaitu seleksi nasional masuk PTN, PTS "tak sehat", kualitas tenaga pendidik (guru),kuliah terbuka online, PAUD, SMA terbuka (gratis), perubahan status PTS menjadi PTN, Ujian Nasional (UN) dan kurikulum 2013

\section{Temuan Penelitian \\ 1.Teks}

Dalam teks tampak pilihan kata yang berbeda pada Kompas, Media Indonesia, dan Republika yang merefleksikan ideologi terkait visi-misi masing-masing surat kabar. Dalam penggunaan kalimat pasif, Kompas, dan Republika dominan menggunakannya untuk meniadakan 


\section{Produksi dan Konsumsi Berita}

Terdapat beberapa konsep dan teori dalam produksi dan konsumsi berita. Dalam produksi berita adalah konsep faktor-faktor yang mempengaruhi isi media, pendekatan agenda media atau agenda-setting approach, dan framingatau pembing kaian, sedangkan dalam konsumsi berita terdiri dari pendekatan penggunaan dan kepuasan media atau uses andgratification approach dan teori ketergantungan media atau media dependancy theory.

Dalam produksi berita, konsep faktor-faktor yang mempengaruhi isi media, yang disebut sebagai memediasi pesan, terdiri dari lima level yaitu level individu pekerja media, level rutin media, level organisasi,level ekstra media, dan level ideologi (Shoemaker dan Reese,1996:85,115,147,183). Dalam agenda media, dikenal pendekatan agenda-setting yaitu terkait dengan pemilihan isu, memuat atau tidak memuat, sehingga mempengaruhi khalayak mengenai apa yang harus dipikirkan dan bagaimana memikirkan objek tertentu(Baran dan Davis, 2010:350). Framing adalah pendekatan untuk melihat bagaimana realitas itu dibentuk, dan dikonstruksi oleh media. Proses pembentukan, dan konstruksi realitas itu, hasil akhirnya adalah adanya bagian tertentu dari realitas yang lebih menonjol, dan lebih mudah dikenali (Eriyanto,2012:66). Dengan begitu, khalayak akan mengingat aspekaspek tertentu yang disajikan dalam teks karena ditonjolkan oleh media. Sebaliknya, aspek yang tidak diberitakan tak diketahui atau dilupakan sehingga sama sekali tidak diperhatikan khalayak. Media mengembangkan konstruksi realitas secara berbeda dengan menggunakan frameatau bingkai yang berbeda karena satu peristiwa dilihat dengan cara yang berbeda oleh suatu media.

Dalam konsumsi berita, konsep motif mengonsumsi media yaitu pendekatan uses \& gratificationatau penggunaan dan kepuasan menjelaskan bagaimana seseorang mengonsumsi media untuk memenuhi kebutuhan,dan keinginannya, dan mendapatkan kepuasan dari pemenuhan kebutuhan melalui media tersebut.Konsumsi media bertujuan dan didorong kebutuhan individu dalam penggunaan media(Severin dan Tankard,1988:332). Ketergantungan sistem media merupakan teori yang mengasumsikan bahwa semakin seseorang menggantungkan kebutuhannya untuk dipenuhi dengan penggunaan media, semakin penting peran media dalam hidup orang tersebut(Baran dan Davis, 2010,340). Ini karena media bekerja dengan cara tertentu dalam suatu sistem sosial tertentu untuk memenuhi keinginan dan kebutuhan khalayak tertentu. Media massa yang selalu tersedia itu berperan penting mensuplai informasi dalam masyarakat yang, pada gilirannya,masyarakat tergantung pada media untuk mengetahui berbagai hal, dan memahami lingkungannya, baik itu peristiwa yang dilihatnya maupun yang tidak langsung dialaminya.

\section{Ideologi}

Ideologi secara sederhana berarti suatu gagasan berdasarkan pemikiran yang sedalam-dalamnya dan merupakan pemikiran falsafah. Dalam hal ini ideologi sebagai suatu 


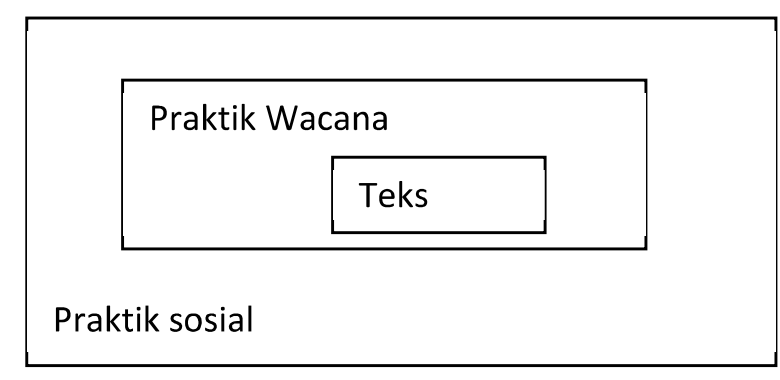

\section{Model Tiga Dimensi Norman Fairclough untuk Analisis Wacana Kritis}

Ketiga dimensi itu tercakup dalam analisis wacana khusus peristiwa komunikatif yang dipusatkan pada (1) ciri-ciri linguistik teks tersebut (teks); (2) proses yang berhubungan dengan produksi dan konsumsi teks itu (praktik wacana); dan (3) praktik sosial yang lebih luas yang mencakup peristiwa komunikatif.

\section{Berita dan Jurnalisme}

Setiap orang butuh berita. Dalam kehidupan sehari-hari, berita menceritakan pada kita apa yang tidak kita alami langsung. Berita adalah sesuatu yang kita tidak tahu sebelumnya, telah lupa atau tidak paham(Roshco,1999:32).Melalui berita selain masyarakat tahu yang belum diketahui, masyarakat teringat kembali akan suatu hal, dan juga menjadi lebih paham tentang hal tersebut.Berita adalah suatu konsekuensi dari keinginan dan kebutuhan manusia untuk tahu sekeliling sosial dan lingkungan fisiknya (Roshco, 1999:33). Hal ini sejalan dengan hakekat manusia yang ingin mengetahui dan memahami berbagai hal di luar dirinya. Berita memberikan khalayak karakter pada peristiwa, maka pertama, berita adalah metode institusional untuk mengupayakan infor- masi tersedia bagi konsumen; kedua, berita adalah penggabungan dari lembaga-lembaga yang sah, ketiga, berita dikumpulkan dan disiarkan oleh profesional yang bekerja di media. Dengan menekankan berita sebagai pengetahuan, maka laporan berita merupakan satu-satunya medium yang membentuk pemahaman dunia sehari-hari (Tuchman, 1978:3).

Namun berita bukan cermin dari realitas. Berita adalah suatu representasi dari dunia dan semua representasi adalah selektif. Artinya orang tertentu membuat keputusan tentang apa yang ditampilkan sebagai berita dan bagaimana menampilkannya (Schudson,2003:33).Berita merupakan refleksi dari realitas, hasil konstruksi dari realitas. Berita merupakan konstruksi sosial dari sebuah realitas.Tindakan media dalam membuat sebuah berita merupakan sebuah konstruksi. Jelaslah, suatu teks (berita) merupakan wacana (tertulis) yang terbentuk dari proses konstruksi realitas.

Tujuan inti dari jurnalisme adalah dan seharusnya tentang memproduksi dan mendistribusikan informasi penting dan perbincangan tentang masalah-masalah sosial, politik dan budaya. Memang beragam personalan diproduksi dalam jurnalisme. Berita merupakan produk dari aktivitas jurnalistik yang dipublikasikan. (Schudson,2003:12).Berbagai kegiatan dan peristiwa yang dilaporkan jurnalis haruslah disebarluaskan dalam media.Fungsi dari jurnalisme itu sangat luas yaitu komunikasi. Jurnalisme adalah usaha atau praktik dari produksi dan penyebaran informasi tentang masalah-masalah masa kini dari minat publik dan kepentinganumum(Schudson,2003:11). 
lebih tinggi dari kalimat atau lebih tinggi dari klausa, dan karenanya untuk mempelajari unit linguistik yang lebih besar, seperti pertukaran percakapan atau teks tertulis. (Schiffrin,1992:1).Analisis wacana juga memperhatikan bahasa dalam penggunaannya di dalam konteks sosial, dan khususnya interaksi atau dialog antara pembicara.Terdapat beberapa asumsi analisis wacana terkait asumsi-asumsi utama bahasa sebagai pusat analisis wacana yang memperhatikan konteks dan komunikasi yaitu bahasa selalu terjadi dalam suatu konteks; bahasa adalah sensitif konteks, bahasa selalu komunikatif dan bahasa dirancang untuk komunikasi (Schiffrin, 1992:3-6).

\section{Analisis Wacana Kritis}

Analisis wacana kritis merupakan pendekatan analisis wacana paling mutahir dan interdisipliner.Analisis wacana kritis mencerminkan dua latar belakang(Subagyo,2009:15-16)

Pertama,dibangun berdasarkan gagasan-gagasan kritis Frankfurt School,khususnya Jurgen Habermas. Kedua, analisis wacana kritis merupakan kelanjutan dari tradisi lingusitik kritisyang merupakan istilah yang pertama kali muncul terkait kajian para pengikut Halliday, utamanya Roger Fowler, Gunter Kress, dan Bob Hodge tentang fungsi bahasa dalam masyarakat.

Analisis Wacana Kritis bisa diidentifikasikan dalam lima ciri umum sebagaimana tinjauan oleh Fairclough dan Wodak yaitu1) Sifat struktur dan proses budaya dan sosial merupakan sebagian linguistik-kewacana-
an.Praktik kewacanaanyaitu teks diproduksi dan dikonsumsi dipandang sebagai bentuk penting praktik sosial;2)Wacana itu tersusun dan bersifat konstitutif. Wacana merupakan bentuk praktik sosial yang menyusun dunia sosial dan disusun oleh praktik-praktik sosial yang lain;3) Penggunaan bahasa Dianalisis secara empiris dalam konteks sosialnya;4) Fungsi wacana secara ideologis. Fokus penelitian analisis wacana kritis merupakan praktik kewacanaan yang mengonstruksi representasi dunia, subjek sosial dan hubungan sosial termasuk hubungan kekuasaan dan peran praktik-praktik wacana untuk melanjutkan kepentingan kelompok-kelompok sosial khusus;5) Penelitian kritis. Analisis wacana kritis tidak bisa dianggap sebagai pendekatan yang secara politik netral, sebagaimana ilmu sosial objektivis, namun sebagai pendekatan kritis yang secara politik ditujukan bagi timbulnya perubahan sosial. Pengritik bertujuan menguak peran praktik kewacanaan dalam melestarikan hubungan kekuasaan yang tidak setara dengan tujuan mempercepat hasil analisis wacana kritis untuk memperjuangkan tercapainya perubahan sosial (Jorgensen dan Phillips,2007:115-121).

Dalam analisis wacana kritis, wacana tidak dipahami semata-mata dalam kajian bahasa meski menggunakan bahasa dalam teks untuk dianalisis namun hasilnya bukan untuk memperoleh gambaran aspek kebahasaan semata,melainkan menghubungkan dengan konteks. Berikut ini gambaran model tiga dimensi oleh Norman Fairclough: 
rutin diagendakan oleh surat kabar Kompas, Media Indonesia, dan Republika. Jurnalisketiga surat kabar sebagai pembuat teks harus memutuskan apa yang akan dimasukkan dan tidak dimasukkan dalam mengontruksi berita pendidikan yang merupakan topik yang menarik dan penting bagi masyarakat ini. Anggapan dasarnya adalah bahwa teks media bukan hanya 'realitas kaca' atau 'mirror realities'sebagaimana yang terkadangdengan naif diperkirakan demikian(Fairclough,1995:103).

Sejalan dengan pemaparan di atas, maka fokus penelitian ini adalah "Ideologi dalam Berita Pendidikan Surat Kabar Kompas, Media Indonesia, dan Republika (Suatu Analisis Wacana Kritis). Menggunakan model analisis wacana kritis Norman Fairclough yang terdiri dari tiga tahapan yakni teks (level mikro), praktik wacana berupa produksi teks dan konsumsi teks (level meso),dan praktik sosial budaya (level makro) dapat ditelusuri wacana yang dikembangkan oleh surat kabar Kompas, MediaIndonesia, dan Republika dalam mengonstruksi berita pendidikan.Berdasarkan fokus penelitian,dapat diuraikan subfokus penelitian yaitu: 1)Ideologi dalam teks berita pendidikan surat kabar Kompas,Media Indonesia, dan Republika dengan mencermati kosakata, tata bahasa (penggunaan kalimat pasif, nominalisasi, modalitas, koherensi lokal), metafora, urutan wacana, unsur relasi dan unsur identitas, dan intertekstualitas; 2)Ideologi dalam praktik wacana surat kabar Kompas, Media Indonesia, dan Republika dengan mencermati produksi teks, dan konsumsi teks; 3). Ideologi dalam praktik sosial budaya surat kabar Kompas, Media Indonesia, dan Republika dengan mencermati lingkup sosial-budaya dalam tiga level yaitu situasional, institusional, dan sosial.

\section{Wacana dan Analisis Wacana}

Wacana seringkali didefinisikan dalam dua cara: unit bahasa khusus di atas kalimat, dan suatu fokus khusus pada penggunaan bahasa (Schiffrin,1994: 20). Wacana dapat juga digunakan merujuk pada konsep seperti genre atau tipe teks; misalnya wacana media yaitu bahasa yang digunakan dalam media (Baker dan Ellece, 2011:310). Beberapa penulis memahami wacana berhubungan dengan topik tertentu, misalnya wacana pendidikan.Berita adalah sebuah wacana,teks dari wacana berita merupakan perwujudan dari wacana berita.

Robert de Beaugrande menyatakan bahwa urutan kalimat atau ujaran (utterance) akan membentuk wacana apabila memenuhi tujuh kriteria kewacanaan yaitu 1) Kohesi (cohesion); 2) Koherensi (coherence); 3)Intensionalitas (intentionnality);4) Akseptabilitas (acceptability);5) Informativitas (informativity); 6)Situasionalitas (situationality)dengan memperhatikan dimensidimensi sebagaimana dikemukakan oleh Hymes yaitu model SPEAKING (Setting-Participans-Ends-Act sequence-Keys Instruments-Norms-Genres);dan7)Intertekstualitas(intertextu ality)(BeaugrandedanDressler, 1981:1 $-13)$.

Brown dan Yule menyatakan analisis wacana adalah analisis bahasa dalam penggunaan. Stubbs mengemukakan analisis wacana untuk mempelajari organisasi bahasa yang 


\title{
IDEOLOGY IN EDUCATION NEWS IN KOMPAS, MEDIA INDONESIA, AND REPUBLIKA NEWSPAPERS \\ (Critical Discourse Analysis)
}

\author{
ROSITA ANGGRAINI \\ rosita.at@gmail.com
}

\begin{abstract}
This study aims to gain deep understanding of ideology in education news in Kompas, Media Indonesia, and Republika newspapers. The method used in this research is qualitative research with content analysis base on the critical discourse analysis theoryby Norman Fairclough that combines three dimensions in communication (text, discourse practice and socio-cultural practice). The data in this research are educational news that is published in Kompas,Media Indonesia, and Republika newspapers in the year 2014. The finding shows that the diversity of ideologies in the text indicate the differences of ideologies of the three newspapers. Ideologies in the discourse practice describe the factors that influence the production of text that are accomodate the issue, routine media and immediacy, selecting and sorting, and influence the view of readers; and affect the consumption of text, i.e read widespread information, integrateprint and digital media, follow the media agenda, read media content as needed, and highly need mass media information.Ideologies in socio-cultural practice describe educational policies in Indonesia.
\end{abstract}

Keywords: discourse, critical discourse analysis, news, ideology.

\section{Pendahuluan}

Wacana media dalam menghadirkan fakta-fakta tak jarang bias, ambigu,dan terdistorsi. Hal ini terjadi dimungkinkan karena dalam mengonstruksi ide-ide untuk teks berita, terdapat peran struktur linguistik. Linguistik sebagai alat analisis wacana yang menguji dasar-dasar ideologis suatu wacana dalam penggunaannya merupakan pilihan yang dapat menggambarkan ideologi yang ingin ditanamkan pada pembacanya baik ideologi media maupun ideologi masyarakat dalam media.

Penelitian ideologi yang dilakukan oleh Yousesefi, Baghban dan Shojaeni (2013) dalam bentuk artikel untuk jurnal, mengekplorasi liputan surat kabar barat yang terbit di Amerika dan Inggris tentang argumentasi yang dibuat melalui headline dan lead berita yang secara ideologis bias terkait liputan sanksi terhadap Iran. Penelitian ini menggunakan instrumen linguistik seperti pilihan leksikal, transivitas, modalitas, metafora, metonimi, presuposisi, dan intertekstualitas. Kesimpulan hasil penelitian menunjukkan bawah headline dan lead berita mengenai pemberitaan sanksi PBB terhadap Iran oleh media barat berdasarkan elemen lingusitik terungkap adanya motivasi ideologis. Media barat memiliki kecenderungan dan orientasi ideologis untuk menggambarkan Iran dalam citra negatif.

Bahasa memang tidak netral. Pilihan bentuk linguistik dalam teks, baik pengeskpresian dengan katakata, atau pilihan sintaksis, didasarkan oleh suatu alasan tertentu. Pilihan bahasa selalu berbeda untuk mengatakan sesuatu yang sama, dan perbedaan dalam ekspresi tersebut membawa perbedaan ideologi. Penelitian artikel ini mengenai ideologiberita pendidikan nasional yang 